\title{
依頼者による医療施設の治験実施体制の評価と問題点
}

\author{
萩森奈央子, ${ }^{*}, a$ 田㠃正信, ${ }^{a}$ 清松和子, ${ }^{a}$ 富安真由美, ${ }^{a}$ 長澤浩平, ${ }^{a}$ \\ 藤戸 $\quad$ 博, ${ }^{b}$ 遠藤恵理華, ${ }^{c}$ 高橋浩二郎, ${ }^{d}$ 玉利一也, ${ }^{d}$ 牛島由美子, ${ }^{d}$ \\ 白石和代, ${ }^{d}$ 竹内綾子, ${ }^{d}$ 北村美奈子, ${ }^{d}$ 末廣 勉, $e$ 大西利彦 $e$
}

\section{Sponsor-based Evaluation of the System for the Execution of Clinical Trial at Hospitals and Related Issues}

\author{
Naoko Hagimori, ${ }^{*, a}$ Masanobu TASAKI, ${ }^{a}$ Kazuko KiYOMATSU, ${ }^{a}$ Mayumi TOMIYASU, ${ }^{a}$ \\ Kohei NAGASAWA,${ }^{a}$ Hiroshi Fujito, ${ }^{b}$ Erika ENDO, ${ }^{c}$ Kojiro TAKAHASHI, ${ }^{d}$ \\ Kazuya TAmari, ${ }^{d}$ Yumiko UshiJima, ${ }^{d}$ Kazuyo Shiraishi, ${ }^{d}$ Ayako TAKeuchi, ${ }^{d}$ \\ Minako Kitamura, ${ }^{d}$ Tsutomu SueHIro, ${ }^{e}$ and Toshihiko ONISHI ${ }^{e}$ \\ ${ }^{a}$ Clinical Trial Center, ${ }^{b}$ Department of Pharmacy, Saga University Hospital, 5-1-1 Nabeshima, Saga 849-8501, \\ Japan, ${ }^{c}$ Faculty of Medicine, Saga University, 5-1-1 Nabeshima, Saga 849-8501, Japan, ${ }^{d}$ Department of \\ Pharmacy, University of Occupational and Environmental Health, Japan, 1-1 Iseigaoka, Yahata-nishi-ku, \\ Kitakyushu 807-8555, Japan, and ${ }^{e}$ Center for Clinical Research, Social Insurance Shimonoseki \\ Kousei Hospital, 3-8 Kamishinchi-machi, Shimonoseki 750-0061, Japan
}

(Received August 8, 2008; Accepted February 2, 2009)

With the revision of the Good Clinical Practice (GCP) in 1997, the Clinical Trial Center was established at Saga University Hospital in 1999, where clinical research coordinators (CRC) of nurses and pharmacists have been carrying out support for clinical trials since June 2000. At present, two pharmacists, two nurses, and three clerical work assistants support the execution of clinical trials; however, in recent years the number of clinical trial commissions has been gradually decreasing. On this occasion, in order to carry out even higher quality and smoother clinical trials, we conducted a questionnaire targeting the sponsors of clinical trials (head monitors) to evaluate this hospital's system for the execution of clinical trials from the sponsor's standpoint. Moreover, for the purpose of comparison with the systems of other institutions, the same questionnaire was conducted on two other hospitals-the University of Occupational and Environmental Health, Japan and the Social Insurance Shimonoseki Kousei Hospital. The problems of the clinical trial execution in our team turned out lack of knowledge concerning GCP and our complex system from the result of the questionnaire.

Key words_— clinical trial; sponsor; evaluation; questionnaire; quality improvement; speed improvement

\section{背景 と目的}

平成 9 年の GCP (Good Clinical Practice) 改正 を受け，佐賀大学医学部附属病院（以下，当院. 図 表中では佐賀大と略記) では平成 11 年より治験セ ンターを設置し，翌年 6 月より薬剤師と看護師の治 験コーディネーター（CRC）による治験業務支援 を開始した。現在，薬剤師 2 名，看護師 2 名，事務 補佐員 3 名による体制で治験の実施を支援している.

$a$ 佐賀大学医学部附属病院治験センター, $b$ 同薬剤部, $c$ 佐賀大学大学院医学研究科, $d$ 産業医科大学病院薬剤 部, e 社会保険下関厚生病院治験支援センター *e-mail: e7298@cc.saga-u.ac.jp
Figure 1 に当院の製造販売後臨床試験を含む治験の 新規受託件数及び契約症例数, 実施率を示している が，新規受託件数は平成 15 年度の 21 件をピークに 平成 17 年度以降減少傾向にあり，これに伴い，契 約症例数も減少している.

今回，この状況を改善し，より良質かつ円滑な治 験の実施に取り組むために, 当院での治験の実施体 制の問題について，依頼者の視点からの評価を試み た。また，他施設との比較を目的として，産業医科 大学病院 (以下, 産業医大) と下関厚生病院 (以下, 下関厚生）を加えた 3 医療施設で同一のアンケート を行った。産業医大及び下関厚生の製造販売後臨床 試験を含む治験の新規受託件数及び契約症例数，実 


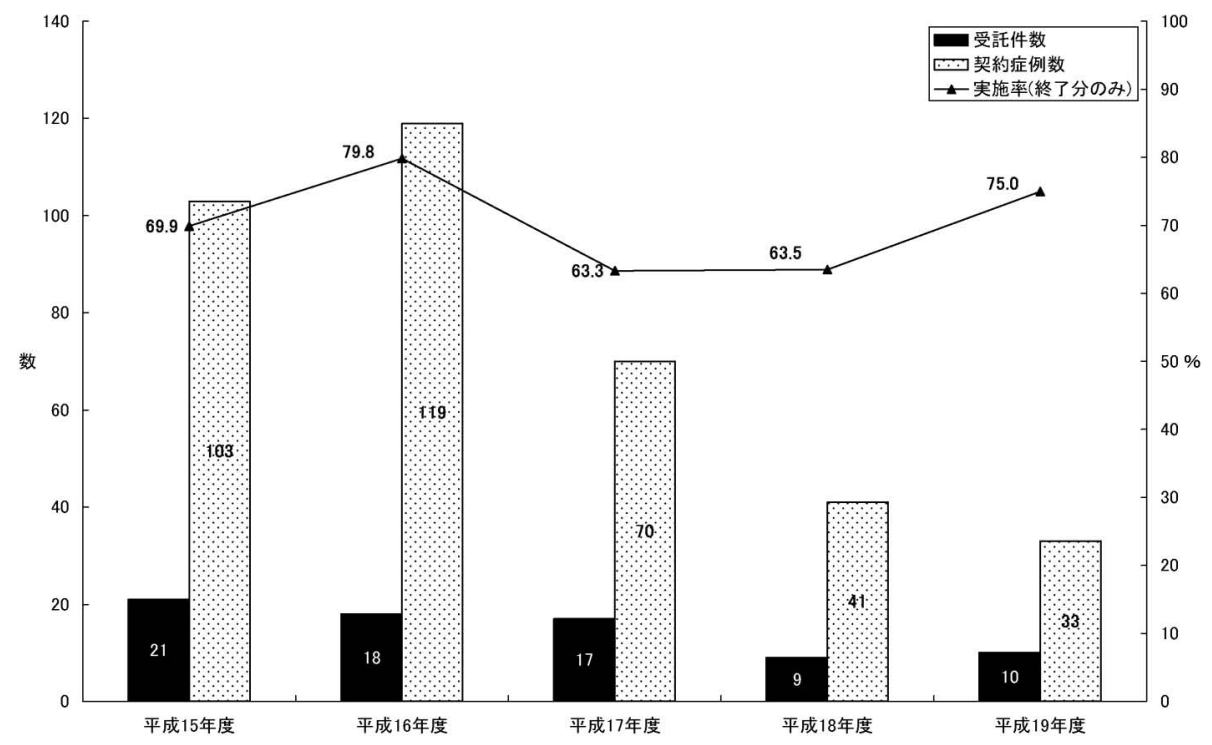

Fig. 1. The Execution Condition of Clinical Trials at Saga University Hospital

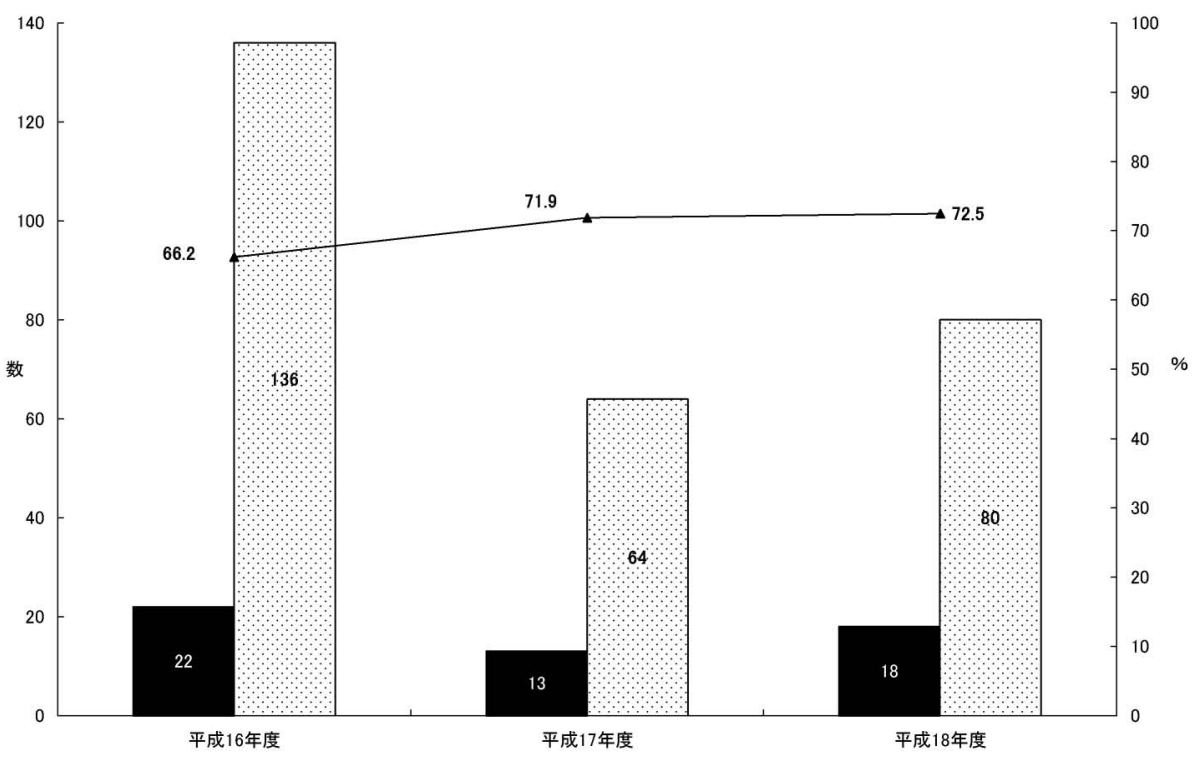

Fig. 3. The Execution Condition of Clinical Trials at the University of Occupational and Environmental Health, Japan

施率を Figs. 3 and 4 に示している. 産業医大は新 規受託件数及び契約症例数が平成 16 年度から平成 17 年度には減少しているものの, 比較的安定して いる。.また，下関厚生は平成 17 年度から治験支援 業務を開始しているが，現在のところ実施率 100\% である。

なお，GCP 省令に起因する実施上の問題は対象 とせず，実施施設での個別の体制を調査し，当院で の問題点を明らかにすることを目的とし，比較対象 として選択した私立の産業医大は一定した治験の新
規受託件数を保ち, 契約症例数も多く, 実施率も上 向きである。下関厚生は，治験業務の支援開始して 2 年であり, 比較的新しい体制で治験を支援する体 制であると考えられる（Table 1)。したがって，こ れらの医療施設と比較することは当院の問題点を明 らかにするために有用であると思われる.

\section{対象と方法}

平成 17 年 4 月から平成 19 年 12 月の間に, 実施 していた治験の依頼者（モニター）を対象としてア 


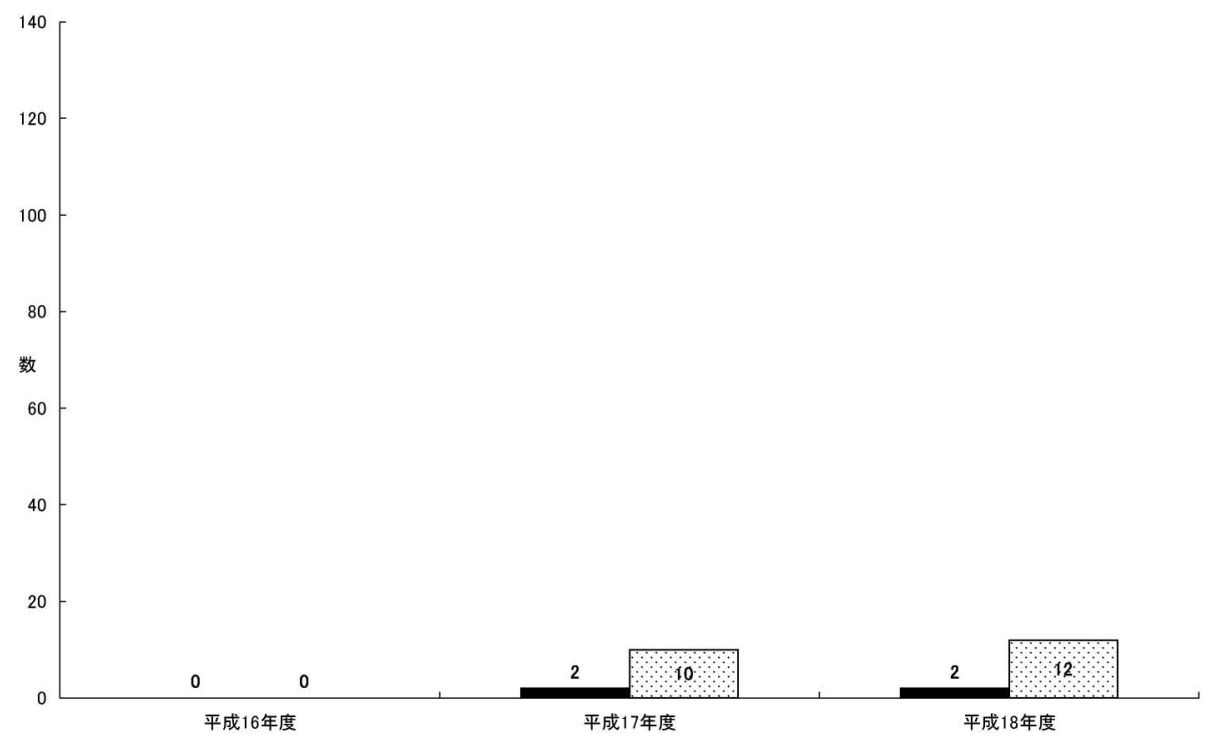

Fig. 4. The Execution Condition of Clinical Trials at the Social Insurance Shimonoseki Kousei Hospital 平成 17 年度の 1 試験のみ終了（実施率 $100 \%$ )。他は継続中.

ンケートを行った。アンケートの調査期間は平成 19 年 12 月 12 日から平成 20 年 1 月 31 日までと し，対象及び調査期間は全医療施設で統一した。ア ンケートは無記名での回答とし，アンケートの配布 及び回収はすべて電子メールを利用した，回答の匿 名性を確保するために，アンケートの回答は各モニ ターから佐賀大学大学院医学研究科の大学院生への 直接送信とし，集計作業についても同部門で実施し た。このことにより，当院を含む各医療施設の治験 スタッフがアンケートの回答者を特定できないよう にした.

本アンケートでは，所属機関種別及び経験年数な どのモニターに関する調査のほか，治験実施医療施 設の選定理由，実施体制に関する満足度などについ て調査した（Table 2)。なお，調査の内容は竹内ら のアンケート1)を参考に作成し，治験の実施体制に 関する満足度は，スピード，コスト（研究費）及び 質について 6 段階評価 $(0 \cdot 2 \cdot 4 \cdot 6 \cdot 8 \cdot 10)$ とし た。また，要望や意見などは記述での回答とした.

なお，国際共同治験については，当院では平成 18 年以降 3 件を受託しており, 全国の状況からも 今後増加することが考えられるため, ${ }^{2-4)}$ 本アン ケートにおいて簡単な調査を行った.

\section{結 果}

1. 設問(1)(2) (3) 回答は 3 医療施設で合計 29
件あり，回収率は $58.2 \%$ であった。このうち 12 件 が開発業務受託機関（CRO）に所属するモニター からの回答であった．経験年数別では経験年数 1 年 というモニターが 7 人と全体で一番多く, ついで 5 年が 5 人であった。医療施設別では，当院では経験 年数 3 年以内のモニターが $46.1 \%$ を占め，ついで 産業医大が $33.3 \%$ ，下関厚生が $25.0 \%$ となってい た。また，勤務地別では東京，大阪の順で多かった が，製薬会社や開発業務受託機関に係わらず，福岡 県などの地方都市に勤務している者もあった。

2. 設問(4)(5) 治験実施施設選定の際の一般的 な理由については，その理由の 1 位は「専門医がい る」 $(58.6 \%)$,「対象疾患患者数が多い」(34.5\%)， 2 位は「対象疾患患者数が多い」(55.1\%)，「専門 医がいる」(31.0\%) であり，「交通の利便性」と 「コスト (研究費)」は選定理由の 1 位にはなかった.

次に，実際に各医療施設を選定した理由について は，当院及び産業医大では「専門医がいる」と「対 象疾患患者数が多い」が理由の 1 位と 2 位の多くの 割合を占めていた。下関厚生では，1 位は「専門医 が多い」が最も多く75.0\%であったが，2 位は「そ の他（学会からの紹介）」が主であった（Fig. 2)

3. 設問6 治験依頼日から契約までの理想的 な期間については，30日という回答が全体の 58.6 \%で一番多く, 平均は 33.4 日で，最短は 14 日，最 長は 90 日であった. 
Table 1. The Each Hospital's System for the Execution of Clinical Trials

\begin{tabular}{|c|c|c|c|c|c|}
\hline & & & 佐賀大 & 産業医大 & 下関厚生 \\
\hline \multirow[t]{2}{*}{ 事務局の人員 } & 事務補佐員 & & $\begin{array}{c}\text { 3名パート } \\
(10: 00-17: 00)\end{array}$ & $\begin{array}{l}\text { 2名アルバイト } \\
(9: 00-17: 00)\end{array}$ & 常勤の薬剂師 CRC が対応 \\
\hline & 薬剤師 & & 1 名（兼任） & 1 名（兼任） & 1 名（専任） \\
\hline \multirow[t]{3}{*}{ 事務局の支援 } & 治験 & & あり & あり & あり \\
\hline & 製造販売後調査 & & あり & なし & あり \\
\hline & 臨床研究 & & あり & なし & あり \\
\hline \multirow[t]{2}{*}{ 事務処理 } & 処理システム & & 独自システム & Microsoft Access & 特になし \\
\hline & 書類の様式 & & 統一様式 & 産業医大の独自様式 & 下関厚生の独自様式 \\
\hline \multirow[t]{3}{*}{$\mathrm{CRC}$} & 常勤薬剂師 & & 1 名（専任） & 2 名（専任） & 1 名（専任） \\
\hline & 常勤看護師 & & 2 名（専任） & 2 名（専任） & 1 名（兼任） \\
\hline & SMO 派遣 CRC & & なし & 2 名（規定日のみ） & なし \\
\hline \multirow[t]{2}{*}{ CRC の支援 } & 治験 & & あり & あり & あり \\
\hline & 臨床研究 & & なし & なし & なし \\
\hline \multicolumn{2}{|l|}{ IRB 開催日 } & & $\begin{array}{l}\text { 毎月第 } 1 \text { 月曜日 } \\
\text { (年 } 12 \text { 回開催) }\end{array}$ & $\begin{array}{l}\text { 毎月第 } 2 \text { 月曜日 } \\
\text { (年 } 12 \text { 回開催) }\end{array}$ & $\begin{array}{l}\text { 月末の金曜早 } \\
\text { (年 } 12 \text { 回開催) }\end{array}$ \\
\hline \multicolumn{2}{|l|}{ IRB 資料 $\nsim$ 切 } & & 毎月 10 日 & 毎月第 3 金曜日 & IRB 開催日の 2 週間前 \\
\hline \multicolumn{2}{|l|}{ 研究費の支払い } & & 前納制 & 前納制 & 出来高払い \\
\hline \multicolumn{2}{|c|}{ CRC 費用算定方法 } & & (単価) × (症例数 $)$ & $\begin{array}{l}\text { (単価) } \times \text { (症例数 }) \\
\quad \times(\text { 実施月数 })\end{array}$ & (単価) $\times$ (症例数 $)$ \\
\hline \multirow[t]{7}{*}{ 治験実施の流れ } & \multirow[t]{7}{*}{ （開催順） } & 1) & $\begin{array}{l}\text { 同意説明文書読み合わ } \\
\text { せ (随時) }\end{array}$ & 1） ヒアリング（毎月第 1 & \multirow{7}{*}{ 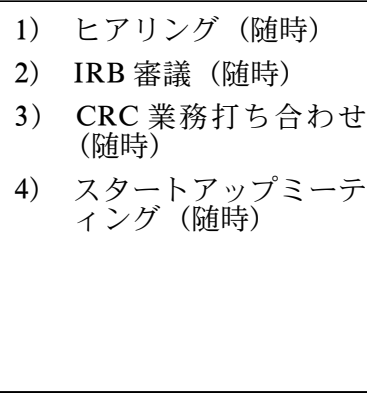 } \\
\hline & & 2) & ヒアリング (随時) & 2) IRB 審議（毎月第 2 & \\
\hline & & 3) & IRB 審議（毎月第 1 & 月曜日) & \\
\hline & & & 月曜） & 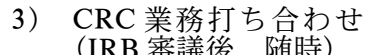 & \\
\hline & & 4) & $\begin{array}{l}\mathrm{CRC} \text { 業務打ち合わせ } \\
\text { (IRB 審議後, 随時) }\end{array}$ & \multirow{3}{*}{$\begin{array}{l}\text { 4） スタートアップミーテ } \\
\text { イング (契約締結後) }\end{array}$} & \\
\hline & & 5) & $\begin{array}{l}\text { スタートアップミーテ } \\
\text { イング (契約締結後) }\end{array}$ & & \\
\hline & & 6) & 薬剂部説明会 & & \\
\hline \multirow[t]{6}{*}{ SDV } & 対応場所 & & 治験センター内 & $\begin{array}{l}\text { SDV 用面談室 - 会議室等 } \\
\text { 随時利用可能 }\end{array}$ & $\begin{array}{l}\text { 治験支援センター内（3 社 } \\
\text { まで対能） }\end{array}$ \\
\hline & 対応場所の数 & & 2 力所（相部屋） & 5 部屋（個室） & $\begin{array}{l}2 \text { 室（内 } 1 \text { 室は可動式の衝 } \\
\text { 立にて } 2 \text { 社対応） }\end{array}$ \\
\hline & $\mathrm{SDV}$ 用電子カルテ台数 & & 2 台 & 5 台 & \multirow{2}{*}{$\begin{array}{l}\text { 電子カルテ未導入 } \\
\text { 急性期の治験を考慮し特に } \\
\text { 期限を設けてない }\end{array}$} \\
\hline & 申込みの期限 & & 原則 7 日前必着 & 原則 7 日前必着 & \\
\hline & 申込み必要書類 & & 申込書 - 通知書 2 通 & （毎回）申請書 & \multirow[t]{2}{*}{ 原資料等閲覧申込書 } \\
\hline & & & & $\begin{array}{c}\text { （初回）手順書, 職務経歴書, } \\
\text { 多一指名書 }\end{array}$ & \\
\hline
\end{tabular}

4. 設問(7) 交通の利便性については, 移動時 間の許容範囲は平均 3.8 時間であり, 各医療施設の 訪問のしやすさについては，当院は「訪問しにくい と」いう回答が $69.2 \%$ であったが，他 2 施設では 「訪問しやすい」が上回っていた。訪問しにくい理 由については, 飛行機やバス, 電車などの接続が悪 く不便であるという意見が多かった。

5. 設問8 「訪問を減らしたりモニタリング を効率的に行ったりするための工夫」については,
「アポイントをまとめる」「電子メール，電話， FAX，郵送を活用する」という回答がそれぞれ 45.9\%，35.1\%を占めていた.

6. 設問 (9) CRC の雇用形態に関して, 医療 施設の CRC（以下，「院内 CRC」）と治験施設支援 機関（SMO）からの派遣 CRC（以下，「派遣 CRC」） のどちらが良いかについては，「院内 CRCが良い」 が $82.8 \%$ であったが，その主な理由は「院内の情 報に精通している」であった（Table 3). 
Table 2. The Questionnaire
(1) あなたの所属機関は製薬会社, 開発業務受託機関のどちらですか.
1. 製薬会社
2. 開発業務受託機関
(2) あなたのモニターとしての経験年数は何年ですか.
（3) あなたの勤務地はどこの都道府県ですか？
(4) 治験を依頼する施設の選定理由について次の中から上位 3 項目（1～3 位）を選択して下さい.
a. 専門医がいる
e. その他
b. 対象疾患患者数が多い
f. その他
c. コスト (研究費)
g. その他
d. 交通の利便性が良い

(5) 当院を選定した理由について次の中から上位 3 項目（1～3 位）を選択して下さい.
a. 専門医がいる
b. 対象疾患患者数が多い
c. コスト (研究費)
d. 交通の利便性が良い

e. その他 (
f. その他 (
g. その他 (

（6) 治験依頼日から契約日までの期間はどれくらいの日数が理想的とお考えですか.

（7) 交通の利便性についての質問です.

1）移動時間の許容範囲はどれくらい（時間）とお考えですか.

2）乗換えの回数や便数の観点から当院は訪問しやすいですか.

1.はい 2. いいえ

3）当院訪問の際に一番困ることは何ですか.

(8) 不必要な訪問を減らしたりモニタリングを効率化するために工夫されていることがあれば教えてください.

(9) 医療機関所属の CRC（院内 CRC）とSMO からの派遣 CRC のどちらが良いとお考えですか. その理由も教えてくださ い. 1 . 院内 CRC 2. 派遣 CRC

(10) 国際共同治験についての質問です.

1）国際共同治験を担当している，または担当したことがありますか.

1.はい 2. いいえ

2）国際共同治験を行うにあたつて医療機関に求めることは何ですか.

(11) EDCについての質問です.

1） EDC を利用した治験を担当されたことはありますか. 1. ある 2. ない

2） EDC は今後治験を行うにあたって不可欠なツールになると思いますか. その理由も教えてください.

(12)当院の電子カルテの閲覧で困ったことがあれば教えてください. 次の13)〜16の各項目について満足度を 6 段階 $(0 \cdot 2 \cdot 4 \cdot 6 \cdot 8 \cdot 10)$ で評価してください.

(13) 実施体制（スピード）について

1）治験依頼日から契約までの期間

2）治験依頼日から契約までの訪問回数

3）契約日から 1 例目の同意取得までの期間

4）全般満足度

(14) 実施体制（コスト）について

1）研究費

2） CRC 経費

3）事前一括払い

4）全般満足度

(15) 実施体制（質）について

1）治験事務局業務について
a. コミュニケーション能力
b. GCP 理解度
c. 申請・諸手続きへの対応
d. 書類の様式
e. ホームページの内容

$\left(\begin{array}{cccccc}\text { 不満足 } & & & & & \text { 大変満足 } \\ 0 & 2 & 4 & 6 & 8 & 10 \\ \hline\end{array}\right.$

\begin{tabular}{llllll}
0 & 2 & 4 & 6 & 8 & 10 \\
\hline 0 & 2 & 4 & 6 & 8 & 10 \\
\hline 0 & 2 & 4 & 6 & 8 & 10 \\
\hline 0 & 2 & 4 & 6 & 8 & 10 \\
\hline
\end{tabular}

\begin{tabular}{llllll}
0 & 2 & 4 & 6 & 8 & 10 \\
\hline 0 & 2 & 4 & 6 & 8 & 10 \\
\hline 0 & 2 & 4 & 6 & 8 & 10 \\
\hline 0 & 2 & 4 & 6 & 8 & 10 \\
\hline
\end{tabular}

\begin{tabular}{llllll}
0 & 2 & 4 & 6 & 8 & 10 \\
\hline 0 & 2 & 4 & 6 & 8 & 10 \\
\hline 0 & 2 & 4 & 6 & 8 & 10 \\
\hline 0 & 2 & 4 & 6 & 8 & 10 \\
\hline 0 & 2 & 4 & 6 & 8 & 10
\end{tabular}


Table 2. The Questionnaire (continue)

2) CRC 業務について

a. コミュニケーション能力

b. GCP 理解度

c. 臨床知識

d. 実施計画書理解度

e. スクリーニング業務

f. 資材管理業務

g. 被験者のスケジュール管理業務

h. デー夕管理業務

i. CRF 作成補助業務

j. SAE 報告書作成補助業務

k. SDV の立会い

3）全般満足度

\begin{tabular}{llllll}
0 & 2 & 4 & 6 & 8 & 10 \\
\hline 0 & 2 & 4 & 6 & 8 & 10 \\
\hline 0 & 2 & 4 & 6 & 8 & 10 \\
\hline 0 & 2 & 4 & 6 & 8 & 10 \\
\hline 0 & 2 & 4 & 6 & 8 & 10 \\
\hline 0 & 2 & 4 & 6 & 8 & 10 \\
\hline 0 & 2 & 4 & 6 & 8 & 10 \\
\hline 0 & 2 & 4 & 6 & 8 & 10 \\
\hline 0 & 2 & 4 & 6 & 8 & 10 \\
\hline 0 & 2 & 4 & 6 & 8 & 10 \\
\hline 0 & 2 & 4 & 6 & 8 & 10 \\
\hline 0 & 2 & 4 & 6 & 8 & 10 \\
\hline & & & & &
\end{tabular}

(16) SDVについて

1）申し込み手続き

2）SDV 実施場所（広さや秘密保全性など）

\begin{tabular}{llllll}
0 & 2 & 4 & 6 & 8 & 10 \\
\hline 0 & 2 & 4 & 6 & 8 & 10 \\
\hline
\end{tabular}

以下の質問は自由回答です．思ったことは何でもお書きください.

(17) 当院における治験実施について問題点があればお書きください.

(18) 当院での治験実施において, GCP の拡大解釈から過剰に要求していることなどオーバークオリティであり緩和して欲し いと思われることがあればお書きください.

(19) もし, あなたが当院の治験事務員または CRCであったとしたら, どうすれば新規治験依頼を増やせると思いますか. 具体的な案や工夫をお書きください. どんなことでもかまいません.

(20) 何か要望があればどんなことでもお書きください.

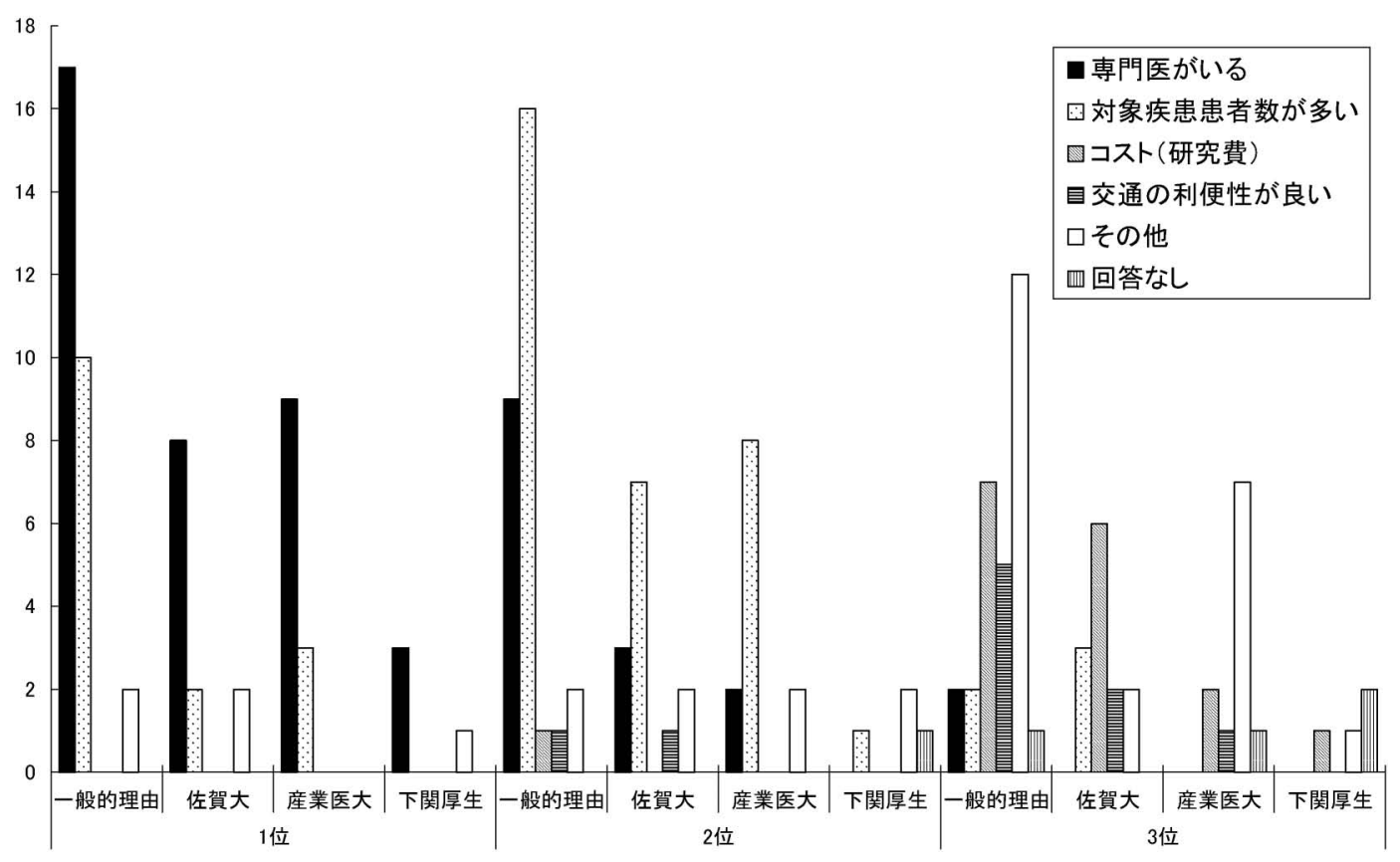

Fig. 2. The Reason to Select Hospitals (question(4)(5) 
Table 3. Advantage with Employment System for CRC (question(9))

院内 CRC が良い理由（複数回答可）（回答数）

・院内の情報（設備・体制・スタッフ）に精通している (18)

・臨機応変に対応可能（特に有害事象発生時）（3

・コストが安い (3)

・終了後の対応が可能 (2)

・派遣 CRC は調査・配置に時間がかかる（2）

・責任をもって仕事をしてくれる（2)

・スクリーニングに関して制約がない（1）

・SMO では CRC 担当者の変更が多く, 逸脱が多い（1）

・医師との信頼関係がある（1）

・現在の院内 CRCが良いので（1）

・他の業務 (調剂など) との掛け持ちがなければ問題ない (1)

派遣 CRC が良い理由（複数回答可）（回答数）

・対応が丁寧でマナーが良い（1）

・担当プロトコールが少なく対応がきめ細かい（1）

・ビジネスとしての認識が高い（1）

・対応が迅速（1）

・早期エントリーが可能 (1)

・院内 CRC は治験と関係ないことにこだわりがあること が多く調整に時間がかかる（1）

7. 設問(10(11) (12) 国際共同治験に関しては，国 際共同治験の経験があるモニターは全体の $13.8 \%$ であった。また，国際共同治験を行うために医療施 設には語学力のあるスタッフの配置や電子症例報告 書などの電子データ収集システム（EDC）導入な どのためのインフラ整備が求められていることが分 かった（Table 4)。EDC に関しては，これを導入 した経験があるモニターは全体の $17.2 \%$ あっった が，将来 EDC は治験の実施に不可欠であると考え ているモニターは 86.2\%であった。その理由とし ては「効率化」「スピードアップ」が挙げられた (Table 5).

電子カルテについての意見では，下関厚生では電 子カルテ未導入であるため, 当院及び産業医大の担 当モニターから回答を得たが，「すべてを閲覧でき ているのか確認が取れない」「医局で電子カルテが 使用できないので困る」との意見が最も多かった.

8. 設問(13)(14)(15)(16) 治験の実施体制に関する満 足度は Table 6 に示すように，スピードと質につい ての全般満足度は当院が最も低く，コストについて は産業医大が最も低かった。

9. 設問(17)(18)(19) 問題点や改善を期待する点
Table 4. Necessary Thing for Executing Global Clinical Trial (question(10)-2)

国際共同治験を行うにあたつて医療機関に求めることは何 ですか.（複数回答可）（回答数）

・語学力 (9)

・インフラ整備（EDC／国際電話） (5)

- 手続きの簡略化・共通化 (2)

・海外の治験の実情の理解（補償も含む）（2）

- 法律の知識 (1)

- 柔軟な対応 (1)

・パソコン操作技術 (1)

・スピードアップ (1)

・教育体制 (1)

・大口の契約症例数を受け入れられる体制（1)

・嫌わないこと（1）

Table 5. Necessity of EDC (question(11)-2)

EDC は今後治験を行うにあたって不可欠なツールになる と思う理由

・SDV の効率化・CRF の早期回収が可能だから（16）

- 進渉状況・安全性の確認がリアルタイムに行えるから（9)

・海外では EDC が主流であるため (3)

・会社の方針（2）

- 将来的に EDC と紙媒体の CRF の両方に対応できる体 制が必要だから（1）

・大規模試験に対応するため (1)

・保管資料の削減につながるため（1）

・コスト削減のため (1)

・医師の手間が省けるため (1)

EDC は今後治験を行うにあたつて不可欠なツールになら ないと思う理由

・システムが煩雑になるから（1）

・1 施設あたりの症例数が少ないと割高になるから（1）

・スタッフへのインストラクションに時間がかかるから（1）

・インフラ整備が困難 (1)

・セキュリティの確保が困難（1）

・電子カルテと連動しないと効率的ではないから（1

などについては Tables 7 and 8 に示した通りであり, 3 医療施設の中で当院に対する指摘が最も多く, そ の内容のほとんどが事務手続きに関することであっ た. Table 9 には治験受託件数を増加させるための モニターとしての意見を示しているが，ホームペー ジやインターネットを用いた事務手続きの簡略化や 実績の公表に関する内容が多かった. 
Table 6. The Results of the Evaluation from the Sponsor's Standpoint (question(13)(14)(15)(16)

\begin{tabular}{|c|c|c|c|}
\hline & $\begin{array}{l}\text { 佐賀大 } \\
(n=13)\end{array}$ & $\begin{array}{c}\text { 産業医大 } \\
(n=12)\end{array}$ & $\begin{array}{c}\text { 下関厚生 } \\
(n=4)\end{array}$ \\
\hline \multicolumn{4}{|l|}{ (13) 実施体制（スピード)について } \\
\hline (13-1） 治験依頼日から契約までの期間 & 5.8 & 7.0 & 8.5 \\
\hline (13-2） 治験依頼日から契約までの訪問回数 & 6.2 & 6.8 & 8.5 \\
\hline (13-3） 契約日から 1 例目の同意取得までの期間 & 5.2 & 6.0 & 5.5 \\
\hline (13)-4） 全般満足度 & 5.7 & 7.3 & 7.5 \\
\hline \multicolumn{4}{|l|}{ (14) 実施体制（コスト)について } \\
\hline (14)-1）研究費 & 7.4 & 6.0 & 7.5 \\
\hline (14-2) CRC 経費 & 7.7 & 6.8 & 7.5 \\
\hline (14)-3）支払い方法 & 3.8 & 3.3 & 8.0 \\
\hline (14)-4） 全般満足度 & 6.5 & 5.9 & 7.5 \\
\hline \multicolumn{4}{|l|}{ (15) 実施体制（質）について } \\
\hline \multicolumn{4}{|l|}{ (15)-1） 治験事務局業務について } \\
\hline a コミュニケーション能力 & 7.7 & 6.8 & 8.0 \\
\hline b GCP 理解度 & 7.4 & 8.0 & 8.5 \\
\hline c 申請・諸手続きへの対応 & 7.2 & 8.2 & 9.0 \\
\hline $\mathrm{d}$ 書類の様式 & 6.0 & 6.3 & 8.5 \\
\hline e ホームページの内容 & 5.7 & 5.7 & 7.5 \\
\hline \multicolumn{4}{|l|}{ (15)-2） CRC 業務について } \\
\hline a コミュニケーション能力 & 8.0 & 7.7 & 8.5 \\
\hline b GCP 理解度 & 7.1 & 7.5 & 8.5 \\
\hline c 臨床知識 & 7.8 & 7.3 & 8.0 \\
\hline $\mathrm{d}$ 実施計画書理解度 & 6.8 & 7.5 & 8.5 \\
\hline e スクリーニング業務 & 6.0 & 6.0 & 8.5 \\
\hline f 資材管理業務 & 7.8 & 7.8 & 9.0 \\
\hline g 被験者のスケジュール管理業務 & 7.8 & 8.7 & 9.0 \\
\hline h デー夕管理業務 & 7.1 & 7.1 & 8.5 \\
\hline i CRF 作成補助業務 & 7.2 & 6.9 & 8.5 \\
\hline j SAE 報告書作成補助業務 & 6.3 & 7.4 & 8.7 \\
\hline k SDV の立会い & 7.2 & 7.5 & 9.5 \\
\hline (15)-3） 全般満足度 & 7.1 & 7.7 & 8.5 \\
\hline \multicolumn{4}{|l|}{ (16) SDVについて } \\
\hline (16-1） 申し込み手続き & 7.1 & 6.4 & 9.0 \\
\hline (16)-2） SDV 実施場所（広さや秘密保全性など） & 7.1 & 8.2 & 8.0 \\
\hline
\end{tabular}

考 察

今回の調査のように，治験実施体制について依頼 者に対するアンケートを行い，複数の医療施設間で
比較検討した例はこれまでに報告されていないた め，非常に興味深い結果が得られた。

1. 選定理由まず, 医療施設の選定に際し て，一般的な医療施設の選定理由と今回調査した 3 
Table 7. Problem of Clinical Trial Execution in Each Hospital (question(17)

当院における治験実施について問題点があればお書き下さ い.（複数回答可）（回答数）

佐賀大 ・他部署との連携が薄い（別部門が多い）(3）

・依頼者との業務分担ができていない（同意説 明文書作成, 他部署との調整, 医師からの捺 印入手) (3)

・院内全体での治験実施体制が確立されていな い（特に，前納制であること）(2)

・院内全体での治験実施体制が確立されていな い（特に，検査部の対応）（1）

・IRB 新規申請手続きが煩雑 (1)

・IRB 締切が早い (1)

- 書類の様式の多さ・特異性 (1)

・同意説明文書が 3 部セットである（1）

- 安全性情報の見解確認を CRC が行わずに事 務員が行うこと（1）

- 直接閲覧申込み期限が早い（1）

・レアケースを想定した質問が多すぎる（1）

・医師の治験に対する理解不足（1）

・スクリーニングのサポートが少ない（1）

・1 例目のエントリーまでの期間が長い（1）

- EDC 用 (SDV 用)の LAN 回線がない（1）

・特になし (4)

産業医大 ・依頼者との業務分担ができていない（他部署 との調整）(2)

・ヒアリングから IRB 審議まで 1 カ月空くの で期間短縮して欲しい(1)

・エントリーが停滞していること（1）

・SDV 用の部屋で携帯電話の電波が入らない こと (1)

・特になし（6）

下関厚生 ・実働 CRC が少ないので効率が悪い（1）

・特になし

(3)

医療施設での実際の選定理由において大きな差はな く,「専門医がいる」「対象疾患患者数が多い」が重 要視されており,「コスト」や「交通の利便性」に は重きが置かれていないと考えられる.

\section{2. 実施体制（スピード）「契約までの期間」} 「契約までの訪問回数」「1 例目の同意取得までの期 間」のいずれの項目も 3 医療施設の中で当院が最低 であった（設問(13)．特に，「契約までの期間」「契 約までの訪問回数」については, Table 1 からも分 かるように，産業医大では事前ヒアリングから治験 審査委員会での初回審議までは 4 週間以上の期間を 要する。一方，当院ではヒアリング等を随時受付と
Table 8. Demands from the Sponsor (question(18)

当院での治験実施において, GCP の拡大解釈から過剩に 要求していることなどオーバークオリティであり緩和して 欲しいと思われることがあればお書き下さい。（複数回答 可）（回答数）

\begin{tabular}{|c|c|}
\hline 佐目 & 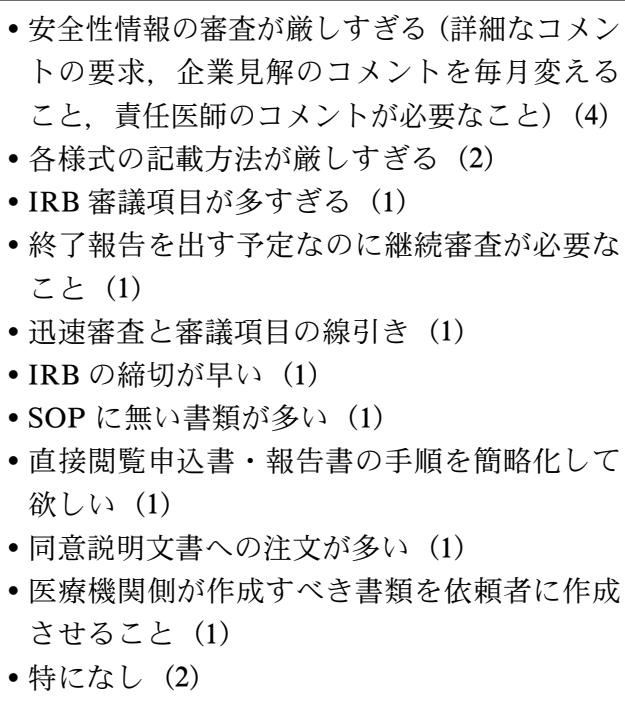 \\
\hline 産業因 & $\begin{array}{l}\text { ・変更申請書の診療科長印を無くして欲しい（1） } \\
\text { ・直接閲覧申請書・報告書は社印・社長印では } \\
\text { なくモニター印にして欲しい（1） } \\
\text { ・ IRB 報告対象事項についての手続き書類は無 } \\
\text { くして欲しい（1） } \\
\text { ・特になし（8） }\end{array}$ \\
\hline & \\
\hline
\end{tabular}

しているにもかかわらず，産業医大よりも明らかに 評価が低かったことから，実際はより手続きに時間 を要しているものと考えられた。そこで，平成 19 年度に依頼のあつた治験について調査したところ, 依頼日から契約締結日までは最短で 8 週間の期間を 要しており, 平均 18 週間（126日）となっていた. これは，依頼者の理想的な期間の 30 日を大幅に超 えている (設問(6)）。この原因の 1 つとして治験審 査委員会申請書類の提出締切日が早いことが考えら れ，また，書類の様式が多く，作成や記載に関して モニターに対し細かい点まで過剩な要求をしている ことも考えられる（設問(17)(18)，加えて，近年増加 傾向にある国際共同治験では，契約に関する日本国 内と海外との考え方の相違から，従来の契約書では 内容を網羅できないため覚書で対応することがあ り，このことが期間を延長させている一因とも考え られる。 
Table 9. Devices That Increases Clinical Trial Request That Monitor Thought about (question(19)

もし，あなたが当院の治験事務員または CRC であったと したらどうすれば新規治験依頼を増やせると思いますか. (複数回答可)（回答数）

\begin{tabular}{|c|c|}
\hline 佐賀大 & 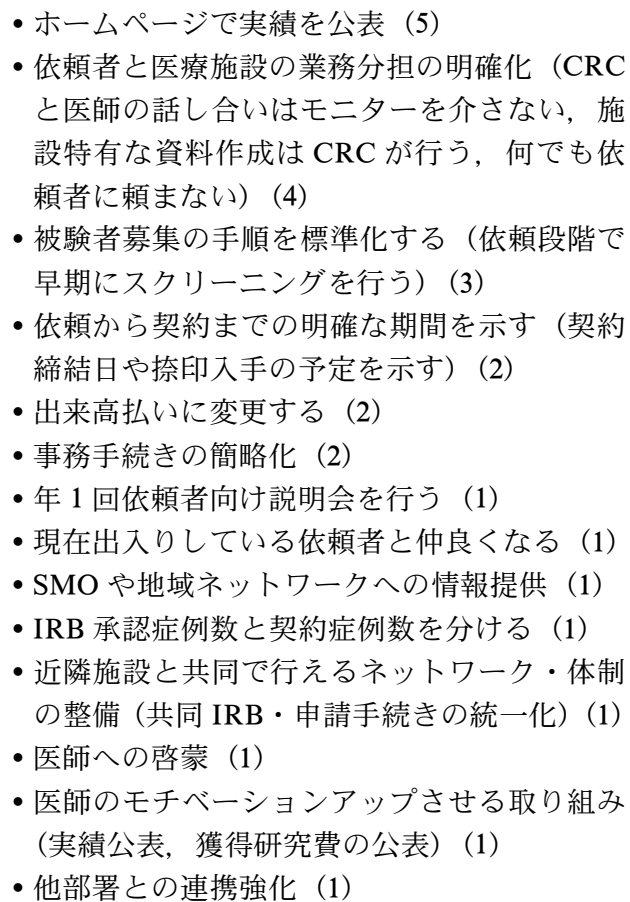 \\
\hline
\end{tabular}

産業医大 ・ホームページの充実（SOP，様式を入手しゃ すくする) (4)

・積極的な姿勢，スクリーニングをする (2)

・実績を公表する（1）

・地域ネットワークを構築する (1)

・柔軟な対応 (1)

- 治験数に見合う CRC の増員 (1)

・出来高払いに変更する（1）

・病院全体で治験をビジネスと考える力を養う (1)

・信頼できる複数のSMOから治験紹介を受 け，依頼者からの直接打診以外のチャンネル を持つこと（1）

下関厚生 ・慢性疾患患者パネルを持つ（2）

- CRC の増員 (1)

- CRF 作成補助業務の充実 (1)

・インターネットを介して新規申請手続きを行 えるようにする (1)

・実績を作る（1）

・治験の経験豊富な医師と CRC の配置（1）

・関連・近隣施設とのネットワークの整備（共 同 IRB，申請手続きの統一化）（1）

また，「1例目の同意取得までの期間」について は，「スクリーニング業務」（設問(15)-2）の結果と合 わせて考えると，より早期の被験者スクリーニング
とスクリーニング業務の充実が求められていること が分かる．このスクリーニング業務に関しては，当 院では十分でないことが問題点として挙げられてお り，かつスクリーニングの早期実施やエントリー促 進のサポートが要望として挙げられていることか ら，スクリーニングを業務として充実させることが 重要と考えられる（設問(17)(18)(19)．

3. 実施体制（コスト） コストに関しては, 支払方法について大きな差がみられた。すなわち， 下関厚生は出来高払いとなっているため，前納制と なっている当院や産業医大と比較して評価が高くな つていた，当院では，契約症例数を実施症例に応じ て段階的に増やしていく方法を取っているため，同 じ前納制の産業医大よりやや評価が高くなっている ものと推測される。しかしながら，この差は軽微で あり依頼者にとってはやはり出来高払いが望ましい ことは明白である。また，医療施設においても，医 師のモチベーションを上げるためには出来高払いが 好ましいと考えられる。

4. 実施体制（質）実施体制についての評価 が低かった要因は，全般的に治験スタッフの GCP 理解度が低く，業務が円滑に進んでいないためと思 われる，CRCの業務に関しては，当院はほかの 2 医療施設と比較して全般的に評価が低く，業務内容 別では，スクリーニング業務，重篤な有害事象 （SAE） 発生報告書作成補助業務，実施計画書理解 度の順に評価が低かった。SAE 発生報告書作成補 助業務に関しては，CRC が行うべき業務をモニ ターが代行した場合があったことから，モニターと の役割分担が明確でないためと考えられる。したが って, SAE 発生時の対応や情報収集やモニターへ の情報の伝達の重要性を CRC が再認識する必要が ある。その上で，「医療機関における業務分担確認 シート」5)を基に，業務分担について再検討しなけ ればならない。また，実施計画書理解度について は，臨床知識について高い評価を得たこと(設問(15) から，実施計画書の理解度が低い要因の 1 つとして GCP 理解度と同様に CRC の人事異動の影響が考 えられる。

CRC の人事異動に関しては, 産業医大は CRC としての採用のため人事異動は原則として退職の場 合のみである。下関厚生では，専任 CRC は異動が 行われず固定されており，兼任 CRC は 2 年のロー 
テーションで配置転換が行われる。一方，当院では 現在 CRC は薬剂部と看護部から約 4 年の任期で治 験センターに配置転換が行われる。しかしながら, 治験事務局の担当者や CRC には知識と経験が必要 であり，また，治験を取り巻く環境は常に変化して いるため，定期的な情報収集に心掛けなければなら ず，頻繁な人事異動は好ましくない.

事務局業務の質に関しては，諸手続き，特に，新 規申請時の手続きへの対応が不十分であると考えら れる。特に他部門との連携がなされていないこと や，書類の作成や記載についてモニターに対して過 剰な要求をしていることが問題点として考えられる (Table 7)。具体的には，他部門との連携とは，契 約や費用などの手続きは別部門で行っているため, 治験センターとは別々にモニターが訪問を行う必要 があったり，検査部との調整をモニターが行ったり している現状を指摘されているものと考えられる.

5. 今後の展望 以上の他施設との比較検討し た結果から，円滑に治験を実施するために，当院に おける治験業務の質の向上とスピードアップの 2 つ の大きな課題が明らかとなり，これらは当院におけ る実施体制の特性に基づくものであった，まず，質 の向上のための業務の効率化については，GCP と 実施計画書を十分に理解し, 治験実施の本質につい て重要である内容とそうでないものを区別すること が必要である．アンケートの結果を受けて，当院の 治験センターでは，毎月スタッフ全員による意見交 換会を行って，具体的な業務の効率化について協議 し，また，治験に係わる知識理解度を深め，治験実 施医療施設としての責務を果たすことを目指してい る. 特に, 新規治験申請時のモニターの負担は書類 の作成のみならず, 責任医師, 分担医師, 関連部署 との調整などにも及ぶことがあったため，モニター の負担を解消できるものと考えている．また，国際 共同治験や EDC の導入が今後増加すると考える依 頼者も多かったことから，これらの受入れ体制の整 備についても検討中である.

もう 1 つの課題であるスピードアップのうち，ま ず，事務手続きについて，先に述べた業務の効率化 により諸手続きに要する時間を削減することが必要 であり，GCPに則した内規や標準手順書（SOP） を用い, 当院独自の書類の種類を減らすことも重要 である.さらに，今回のアンケートではホームペー
ジに関する意見が多数みられ，モニターがホーム ページを活用して事務手続きを効率化することを求 めていることが分かった。特に，モニターへの SOP や様式の提供をスムーズにすることにより， 依頼日から契約締結までの期間を短縮することが必 要である。また，諸手続きの流れについてモニター 向けの説明用資料を作成し，作業を明解に行えるよ うに配慮した。

今回，モニターによるアンケートの結果を複数の 医療施設と比較することにより当院における治験の 問題点が明らかとなった.

治験を実施する上で最も重要なことの 1 つは，治 験を早期に開始し短期間で終了することである。そ のために，CRC 業務において重要なことは，第 1 に治験依頼時における早期のスクリーニングを実施 することで，当院における実施可能な契約症例数を 定めることができ，また当院における初回被験者登 録をより早期に行える，第 2 には，適切なデー夕管 理を行い，医師の症例報告書作成を支援することが 重要であり,これにより依頼者への適切かつ早期の 情報伝達が可能になる．特に，「合併症」「既往歴」 「併用薬」「有害事象」などの確認は被験者の安全性 確保には欠かせない情報であり，これを整理してお くことはモニターの直接閲覧の作業効率を上げるこ とにもつながる. ${ }^{6}$

また，交通の利便性については，治験実施医療施 設選定の大きな理由にはならないものの，近隣の医 療施設と治験ネットワークを確立することにより， モニターの移動に掛かる作業効率化を図り，併せて 治験審査委員会の審査等に係わる事務手続きの効率 化が望まれるため，当院を中心とした地域の治験ネ ットワークの設置準備中である.

\section{ま と め}

1997 年に新 GCP が制定され，その後，全国で治 験管理センターや臨床試験センターなどを設置する 医療施設が増加し，かつ CRC という職種が誕生し て 10 年が経過し, 日本国内での治験の実施環境は 整備されつつある。しかしながら，治験スタッフの 質的及び量的不足，非効率的な事務手続きは依然と して解消できておらず，さらに治験のグローバル化 などの様々な環境変化に対応するためにも，よりよ い治験の実施環境整備が今後も必要である。 2,7$)$ 平成 
19 年度の「新たな治験活性化 5 力年計画」におい ても，事務手続きや処理体制の効率化と治験スタッ フの育成と確保が課題として取り上げられてお り，2）また，依頼者から医療施設に対し，治験業務 の効率化を求める意見も散見されるようになつ た. 6,8,9) すなわち，前述のような当院の課題は，全 国の治験実施医療施設が抱える問題であると考えら れる。そのため，日本における治験の実施を推進 し，より早く医薬品を患者の元へ届けるためには， 治験実施医療施設がクオリティアップとスピードア ップを目指した業務の効率化を行い，依頼者と医療 施設の責任範囲を明確にし，その責務を果たすこと が重要である.

謝辞 アンケートにご協力頂いた産業医科大学 病院薬剂部並びに社会保険下関厚生病院治験支援セ ンターの皆様に深く感謝致します。また，アンケー トにご回答頂いた各社のモニターの皆様に深く感謝 致します。

\section{REFERENCES}

1) Takeuchi A., Hagimori (Mizuyama) N., Ushijima Y., Shiraishi K., Tamari K., Takahashi K., Abstracts of papers, The 4th CRC to Rinshoshiken no Arikata wo Kangaeru Kaigi,
P. 49.

2) The Ministry of Education, Culture, Sports, Science, and Technology; JAPAN and The Ministry of Health, Labour and Welfare; JAPAN, Mon. Inst. Health Econ. Policy, 154, 2-24 (2007).

3) Ohashi K., Jpn. J. Clin. Pharmacol. Ther., 39 (2) , 68-70 (2008) .

4) Obayashi M., Iwasaki T., Sato D., Doi O., "Jitsurei kara Manabu Global ChikenKaizen ni Muketa Torikumi to Kadai-," JIHO, 2007.

5) Japan Pharmaceutical Manufacturers Association: 〈http://www.jpma.or.jp/about/board/ evaluation/allotment/ $\rangle$, confirmed. html (Aug., 2008).

6) Japan Pharmaceutical Manufacturers Association, "Koritsutekina Chiken Gyomu no Yakuwari Buntan nitsuite - Iraisha kara no Teian-," Iyaku Shuppan Center, 2007.

7) Nakamura T., Jpn. J. Clin. Pharmacol. Ther., 39 (2), 39-50 (2008).

8) Nishimura (Suzuki) T., Tanizawa K., Kobayashi F., Doi O., "Jitsurei kara Saguru GCP Over Quality Mondai to Kaiketsu heno Teigen," JIHO, 2008.

9) Ishibashi K., Off. Pharm. Ind. Res. News, 24, 17-20 (2008). 